\title{
A methane seep area in the Skagerrak, the habitat of the pogonophore Siboglinum poseidoni and the bivalve mollusc Thyasira sarsi
}

\author{
P. R. Dando ${ }^{1}$, I. Bussmann ${ }^{2}$, S. J. Niven ${ }^{1}$, S. C. M. O'Hara ${ }^{1,3}$, R. Schmaljohann ${ }^{4}$ \\ L. J. Taylor ${ }^{1}$ \\ ${ }^{1}$ Marine Biological Association of the United Kingdom, Citadel Hill, Plymouth PL1 2PB, United Kingdom \\ ${ }^{2}$ Universität Kiel, Sonderforschungsbereich, Olshausenstrasse 40, D-24118 Kiel, Germany \\ ${ }^{3}$ Plymouth Marine Laboratory, Citadel Hill, Plymouth PL1 2PB, United Kingdom \\ ${ }^{4}$ Institut für Meereskunde an der Universität Kiel, Düsternbrooker Weg 20, D-24105 Kiel, Germany
}

\begin{abstract}
On the southern slope of the central Skagerrak there are locally abundant populations of the pogonophore Siboglinum poseidoni, which lives on symbiotic methanotrophic bacteria, and the bivalve Thyasira sarsi, which lives on symbiotic sulphur-oxidising bacteria. Investigations have been made on the environmental factors influencing these populations, notably the methane content of the sediment, the rate of sulphate reduction and the distribution of reduced sulphur species. The subsurface gas distribution was investigated using a deep-tow boomer and sediment cores were collected from both seep and non-seep areas. Methane-saturated sediment, detected by acoustic blanking, was found within $3 \mathrm{~m}$ of the sediment surface in water depths from $<55 \mathrm{~m}$ to $360 \mathrm{~m}$. At greater water depths the blanking was less shallow, sharply declining to $100 \mathrm{~ms} \mathrm{2-way} \mathrm{travel} \mathrm{time} \mathrm{at} 390 \mathrm{~m}$. There was no evidence for outgassing over most of the survey area. Seeps and their specialised fauna were found on a steeper section of the slope where slumping of the sediment exposed underlying gas-saturated layers. The seeps were small and localised and were estimated to occupy $2.3 \%$ of the area of this zone. In seep sediments the potential aerobic methane oxidation rates were 40 -fold higher than in non-seep sediments, while the actual rates, measured by a radiotracer technique, were up to 460 -fold higher in the surface sediment at the seeps. Within the seep sediments there was a greatly reduced sulphate concentration, down to $6 \times 10^{3} \mathrm{\mu g}$-at. S I-1 , in the upper $10 \mathrm{~cm}$, compared with $30 \times 10^{3} \mu \mathrm{g}-\mathrm{at} . \mathrm{S} \mathrm{I}^{-1}$ at a distance of $30 \mathrm{~cm}$ from the seep. Correspondingly, rates of sulphate reduction were very much greater at the seeps, 500 to $2000 \mu \mathrm{g}$-at. S reduced $\mathrm{dm}^{-3} \mathrm{~d}^{-1}$, compared with approximately $50 \mu \mathrm{g}$-at. S reduced $\mathrm{dm}^{-3} \mathrm{~d}^{-1}$ in non-seep sediment. Very high methane concentrations were found where $S$. poseidoni was abundant, up to $3.4 \times 10^{3} \mu \mathrm{mol} \mathrm{dm^{-3 }}$ in the upper $10 \mathrm{~cm}$ of the sediment. Dissolved sulphide was also much enriched at the seeps, to $500 \mu \mathrm{g}$-at. $\mathrm{S} \mathrm{l}^{-1}$ pore water, explaining the abundant populations of T. sarsi. These 2 species made up the bulk of the infaunal biomass at the seeps, whereas polychaetes dominated in non-seep sediments. The biomass of the macrofauna was 3 -fold higher in seep than in non-seep sediment.
\end{abstract}

KEY WORDS: Methane seeps · Skagerrak · Sulphide $\cdot$ Siboglinum poseidoni $\cdot$ Thyasira sarsi Sulphate reduction - Methane oxidation

\section{INTRODUCTION}

The southern part of the Skagerrak, from the Danish coast to the midline, is an area which has been subject to heavy sedimentation and contains a large area of gas-saturated sediment (van Weering et al. 1973, van Weering 1975, Hovland 1991). Siboglinum poseidoni, a perviate pogonophore which lives on endosymbiotic methane-oxidising bacteria, has been described from this area (Southward et al. 1981. Flügel \& Langhof 1983, Schmaljohann \& Flügel 1987) and has recently been reported to be located at small methane seeps (Flügel \& Callsen-Cencic 1992). With the exception of some vent and seep mytilids (Cavanaugh et al. 1987, 
Childress et al. 1986, Cavanaugh et al. 1992), these pogonophores are the only animals currently known to derive most of their nutrition from methane. They have tissue carbon heavily depleted in ${ }^{13} \mathrm{C}$, with $\delta^{13} \mathrm{C}=-73.6$ to $-78.3 \%$ (Schmaljohann et al. 1990). Associated with $S$. poseidoni is the bivalve mollusc Thyasira sarsi (Schmaljohann et al. 1990), a species normally living on endosymbiotic sulphur-oxidising bacteria (Dando \& Southward 1986, Dando \& Spiro 1993) and which has been shown to be associated with methane seep sites in the North Sea (Dando et al. 1991).

The objectives of this study were to investigate more fully the habitat of these animals in the Skagerrak and to define the conditions which give rise to this ecosystem.

\section{METHODS}

The area surveyed and sampled on RRS 'Challenger' cruise 82, from 20 to 29 July 1991, is shown in Fig. 1. It included the position $58^{\circ} 1.3^{\prime} \mathrm{N}, 9^{\circ} 34.6^{\prime} \mathrm{E}$, in which the pogonophores had previously been located (Flugei \& Langhof 1983). Acoustic surveys were carried out using a Simrad EA500 echo sounder with 11 and $12.5 \mathrm{kHz}$ transducers and the British Geological Survey's (BGS) deep-tow boomer. The track plots for the 53 survey lines are shown in Fig. 1.

Sediment samples were collected in a $0.5 \times 0.5 \mathrm{~m}$ box corer. PVC tubes of $100 \mathrm{~mm}$ i.d. were used to take subcores from the box for sediment chemistry. Subsamples

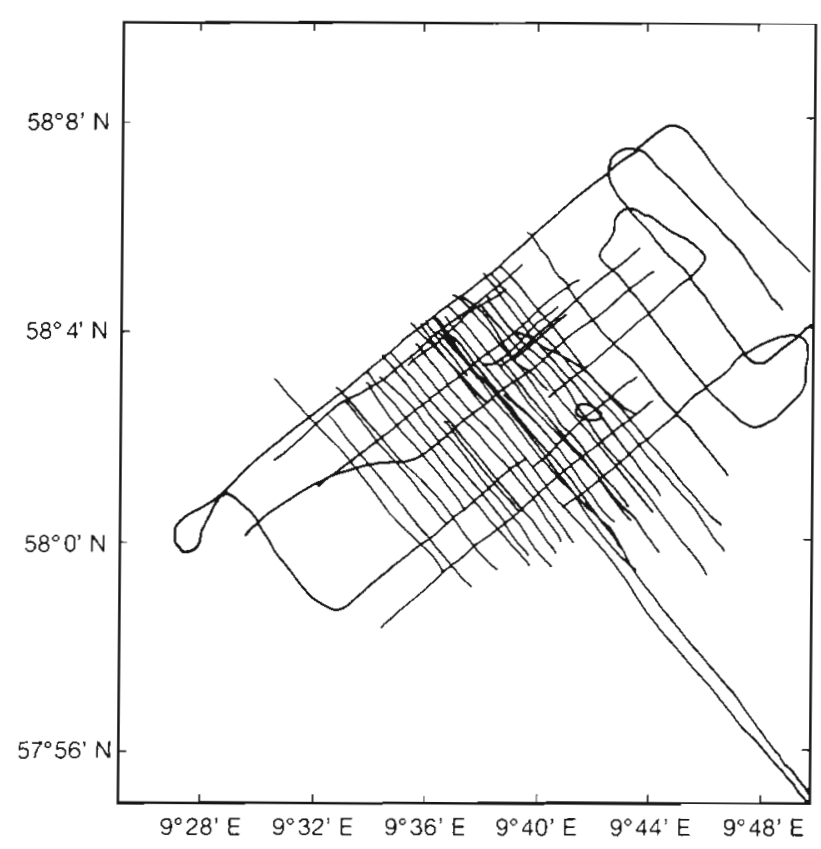

Fig. 1. Survey lines on 'Challenger' cruise 82 in the Skagerrak were removed at 2,5 or $10 \mathrm{~cm}$ intervals down the depth of the core using cut-off polystyrene syringes. After the subcores had been positioned, the side of the box was removed to allow examination of the sediment structure and to enable samples for macrofaunal determination to be removed from different horizons. Sediment subsamples were also taken from different horizons after sediment lying near to the removed side had been scraped away. Additional sediment was collected using a multiple corer to examine undisturbed sediment surface and a Kasten corer to look at deeper horizons. Sediment temperatures were in the range 6.3 to $6.6^{\circ} \mathrm{C}$.

Sediment subsampling and analytical methods for gases, iron sulphides, elemental sulphur, sulphate and sulphate reduction rates followed those previously described (Dando et al. 1991). Dissolved sulphide, sulphite and thiosulphate were derivatised with monobromobimane under argon and the derivatives separated by HPLC and measured by fluorescence (Newton et al. 1981).

Sealed $4 \mathrm{ml}$ syringe cores were injected with $5 \mu \mathrm{l}$ of $\mathrm{K}_{2}{ }^{35} \mathrm{SO}_{4}$ along the centre of the core and incubated in the dark for 12 to $15 \mathrm{~h}$ at $6^{\circ} \mathrm{C}$. At the end of the incubation the sediment was extruded into glass vials containing $4 \mathrm{ml} 5 \%$ neutralised zinc acetate solution. This precipitated any hydrogen sulphide and stopped further bacterial activity. The samples were then frozen until analysis when reduced sulphur species were all converted to hydrogen sulphide by reaction with acidified chromous chloride solution (Zhabina \& Volkov 1978). The $\mathrm{H}_{2} \mathrm{~S}$ released was trapped in zinc acetate solution, mixed with scintillant (Packard Instagel) and the amount of ${ }^{35} \mathrm{SO}_{4}=$ reduced determined by scintillation counting, using the external standard channel ratios method for quench correction. The radioactivity of the ${ }^{35} \mathrm{SO}_{4}=$ remaining was determined by scintillation counting of sediment washings. Sulphate concentrations in the interstitial water were determined by ion chromatography and the water content of the sediment was measured by drying the sediment to constant weight at $60^{\circ} \mathrm{C}$. Sulphate reduction rates were calculated by multiplying the proportion of the total ${ }^{35} \mathrm{~S}$ reduced by the fractionation factor and by the dissolved sulphate $\mathrm{dm}^{-3}$ sediment (Jørgensen 1978).

Methane oxidation rates were determined by 2 methods. In near-surface layers the potential rate of aerobic oxidation was determined by incubating a sediment suspension under a methane/air gas phase which gave a final concentration in the aqueous phase of $1 \mu \mathrm{M}$ methane. The consumption of methane was followed by gas chromatography.

The rate of methane oxidation under in situ oxygen and methane concentrations was determined by injection of ${ }^{14} \mathrm{C}$-labelled methane (prepared from meth- 
anogen cultures by U. Schuster, Univ. of Essex, UK) into intact sediment subsamples (Iversen \& Jørgensen 1985) contained in $5 \mathrm{ml}$ polystyrene syringes (Sabre) which were sealed with butyl rubber bungs. 20 to $50 \mu \mathrm{l}$ of an anoxic solution of artificial seawater $(30 \%)$, containing $2 \mu \mathrm{l}$ methane $\mathrm{ml}^{-1}$, was injected through the rubber plunger seal of the syringe along the length of the sediment core. The syringe samples were then incubated at $6^{\circ} \mathrm{C}$ in the dark for $12 \mathrm{~h}$. Incubation was stopped by pushing the sediment into gas-tight glass vials prefilled with $5 \mathrm{ml} 2 \mathrm{~N} \mathrm{NaOH}$. This stopped the bacterial activity and trapped the ${ }^{14} \mathrm{C}$-bicarbonate. The amounts of ${ }^{14} \mathrm{CO}_{2}$ and ${ }^{14} \mathrm{CH}_{4}$ in the vials were determined according to Iversen \& Jørgensen (1985). Carbon dioxide was trapped after acidification of the sediment. Additionally, the amount of radioactivity fixed as organic carbon in the sediment was determined in triplicate by combusting the dried sediment with a Packard sample oxidiser and determining the activity of the $\mathrm{CO}_{2}$ released by scintillation counting. Radioactivity in the different fractions was estimated using a Beckman LS scintillation counter with quench corrections based on external standards and channel ratios. Rates of methane oxidation in the sediment were calculated from the amount of ${ }^{14} \mathrm{CO}_{2}$ and ${ }^{14} \mathrm{C}_{\text {assimilated }}$ formed in the sediment and from the concentration and radioactivity of the methane. The rates of oxidation were shown to be linear with time in pilot studies up to $24 \mathrm{~h}$ and therefore only end-point determinations were applied to most samples.

Chemical concentrations and rate measurements are reported per $\mathrm{dm}^{3}$ sediment, or per litre of extracted interstitial water.

Direct counts of bacterial numbers were made using epifluorescence microscopy of sonicated, diluted sediment samples stained with acridine orange. The fauna was collected by sieving the sediment through a mesh of $500 \mu \mathrm{m}$ diameter, fixed in buffered $2 \%$ formalin in seawater and transferred to $75 \%$ ethanol.

\section{RESULTS}

The survey area covered water depths from 55 to $425 \mathrm{~m}$; the bathymetry is plotted in Fig. 2. The deeptow boomer records showed acoustic blanking, regions of sediment through which sound waves would not penetrate, aver most of the area. From shallower than $55 \mathrm{~m}$ water depth (the shallowest part of the slope investigated) downslope to approximately $360 \mathrm{~m}$ the blanking started within the upper $3 \mathrm{~m}$ of the sedimentary column (Figs. $3 \& 4$ ). This blanking also showed as a strong reflector on the Simrad EA500 echo sounder records. The positions of sediment cores taken are

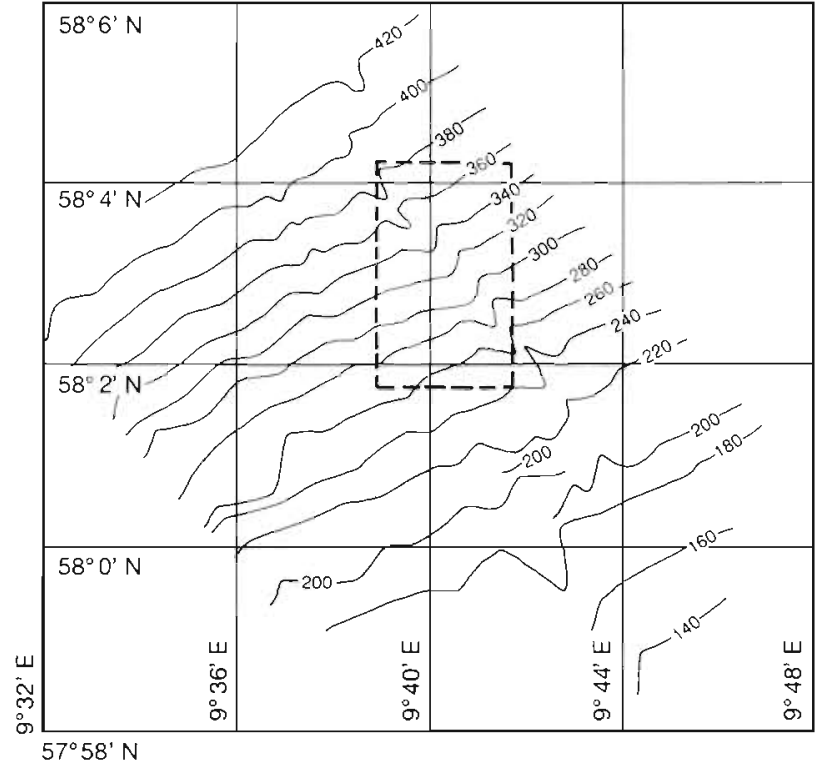

Fig. 2. Bathymetry of survey area. Rectangle shows the larger area (shown in Fig. 5) studied by means of sediment cores

shown in Fig 5. Confirmation that the acoustic blanking was due to gas bubbles was obtained from 4 Kasten core samples taken in positions where the acoustic blanking approached the sediment surface, Stns 45 , 94, 112 and 114 (Fig. 5) in water depths of 321, 305, 358 and $366 \mathrm{~m}$ respectively. Gas bubbles were observed in these cores at sub-bottom depths of, respectively, 1.55 , $0.83,1.35$ and $0.62 \mathrm{~m}$. In addition box cores at Stns 61 , 71 and 105 (Fig. 5) showed gas bubbles venting from part of the core surface and the core at Stn 106 showed a dome of sulphide-rich and methane-rich mud rising from part of the base of the core to within $20 \mathrm{~cm}$ of the sediment surface.

The sediment depth at which acoustic blanking occurred increased to $20 \mathrm{~ms}$ at $360 \mathrm{~m}$ water depth and then sharply dropped below the depth of acoustic penetration by the boomer, $100 \mathrm{~ms} 2$-way travel time, at approximately $390 \mathrm{~m}$ water depth (Fig. 3). North of this deeper boundary a few 'plumes' of gas-charged sediment were observed (Figs. $4 \& 6$ ).

An area of hummocks and sediment slumps (Figs. 3 \& 4) was associated with a slight increase in the slope of the seabed to $1.61 \pm 0.18^{\circ}$, starting at approximately $280 \mathrm{~m}$ water depth and continuing to the region where the depth of sediment gas saturation, as determined by acoustic blanking on the boomer records, fell below $20 \mathrm{~ms}$ at $360 \mathrm{~m}$ water depth. Sediment core sampling was concentrated in this zone of sediment slumps. Within this region 44 box core samples were collected, only 3 of which had high methane concentrations in the surface sediment. 


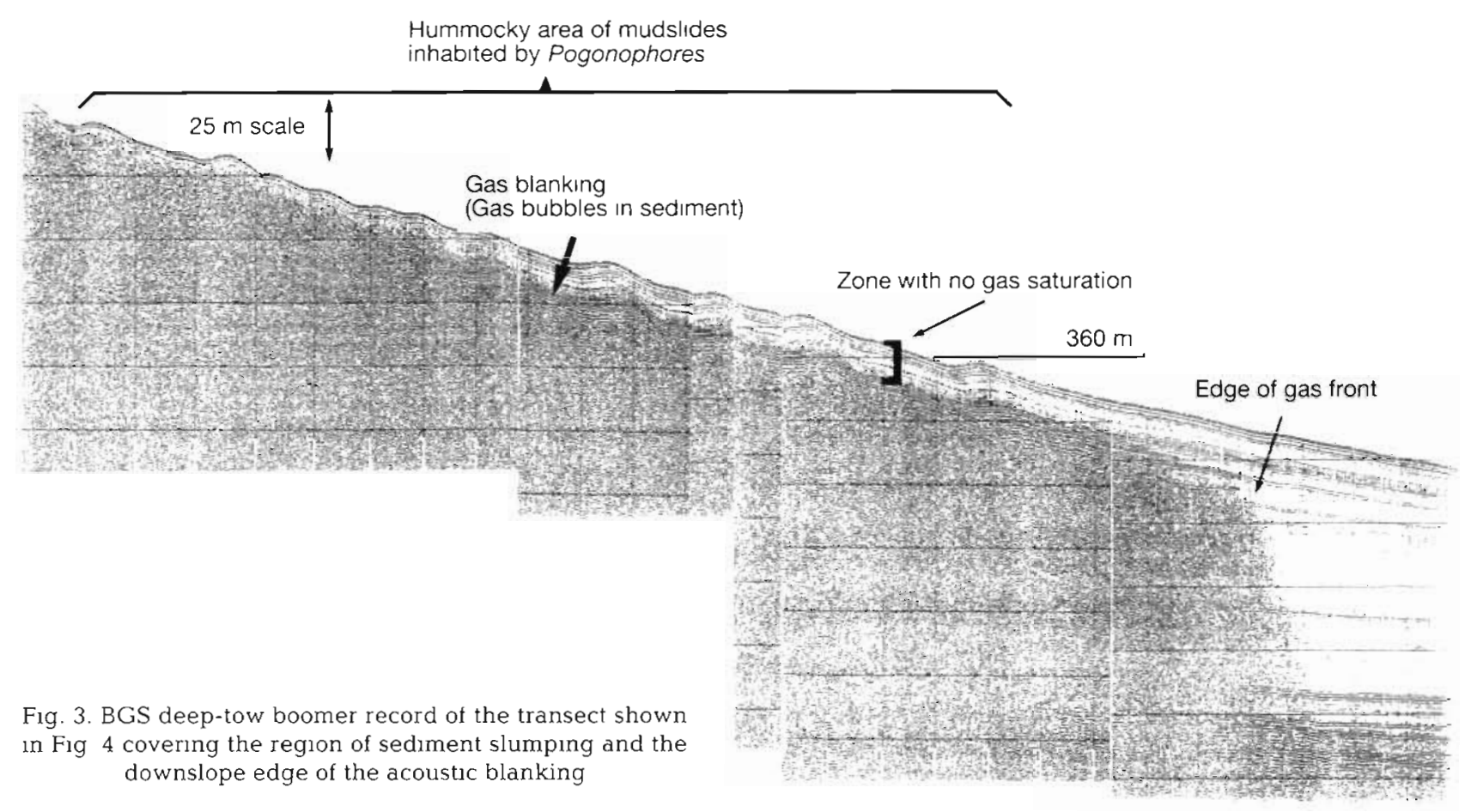

Geochemical profiles were determined on 14 cores. Typical sediment profiles for methane, methane oxıdation rates, sulphate, sulphate reduction, soluble and insoluble sulphur species, ammonia, $\mathrm{pH}$ and water content are shown for a core from $\operatorname{Stn} 35$ at $323 \mathrm{~m}$ water depth (Fig. 7). In most cores sampled the

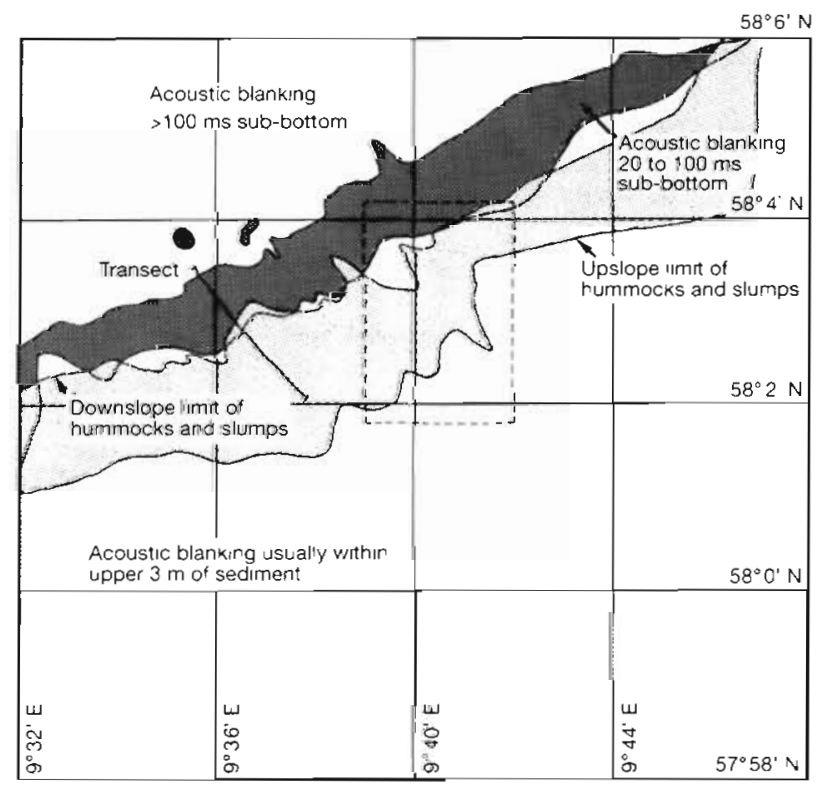

Fig 4 Map of the survey area showing region of shallow gassaturated sediment and area of sediment hummocks and slumps. The rectangle shows the larger area (shown in Fig 5 ) studıed by means of sediment cores methane concentrations in the upper $10 \mathrm{~cm}$ of sediment were $<1 \mu \mathrm{mol} \mathrm{dm}{ }^{-3}$ sediment. The depth profiles indicate that, in most cases, methane is consumed within the upper $10 \mathrm{~cm}$ of the sediment and does not diffuse into the overlying seawater. Below approximately $10 \mathrm{~cm}$ sediment depth the methane concentrations increased with depth until visible bubble formation occurred at concentrations of approximately $3 \times$ $10^{3} \mu \mathrm{mol} \mathrm{dm}{ }^{-3}$ sediment. Aerobic methane oxidation rates in sediment samples exposed to air were normally below $2.4 \mu \mathrm{mol} \mathrm{dm} \mathrm{dm}^{-3} \mathrm{~d}^{-1}$ in the upper $10 \mathrm{~cm}$ of sedıment, with an integrated rate of $17.5 \pm 4.7$ (SD) $\mu \mathrm{mol} \mathrm{m} \mathrm{m}^{-2} \mathrm{~d}^{-1}$ for the upper $8 \mathrm{~cm}$ of sediment. The tracer injection method gave oxidation rates of $1.6 \mu \mathrm{mol} \mathrm{dm} \mathrm{dm}^{-3} \mathrm{~d}^{-1}$ at the surface, decreasing with depth to at least $42 \mathrm{~cm}$, e.g. the box core at Stn 81 (Fig. 8). Deeper in the sediment rates increased again, for example in the methane-saturated sediment from the Kasten core at Stn 45 samples from 140 to $320 \mathrm{~cm}$ depth sub-bottom showed a mean oxidation rate of $12.0 \mu \mathrm{mol} \mathrm{dm}^{-3} \mathrm{~d}^{-1}$ (Fig. 9a).

The sulphate concentrations in the interstitial water of most cores did not fall below $20 \times 10^{3} \mu \mathrm{g}$-at. S $\mathrm{I}^{-1}$ in the upper $50 \mathrm{~cm}$ of the sediment (Figs. $7 \mathrm{~b} \& 8 \mathrm{~b}$ ). Integrated sulphate reduction rates for the upper $40 \mathrm{~cm}$ of sediment were in the range $4.5 \times 10^{3}$ to $15.1 \times 10^{3}$, mean $7.2 \times 10^{3} \pm 3.1 \times 10^{3}$ (SD) $\mu$ g-at. sulphate $\mathrm{S}$ reduced $\mathrm{m}^{-2} \mathrm{~d}^{-1}$. Acid-labile sulphide concentrations and chromous-reducible sulphide concentrations in the sediment were high, both reaching up to $48 \times 10^{3}$ $\mu \mathrm{g}$-at. $\mathrm{S} \mathrm{dm}{ }^{-3}$ in the upper $50 \mathrm{~cm}$ of sediment. Sulphide 
Fig. 5. Positions of sediment cores taken. Expanded section shows the detail of core positions in the seep area; co-ordinates are shown as decimal degrees. The position of Kastenlot cores (a) and box cores containing seep sediment $(\bullet)$ or non-seep sediment (O) are marked

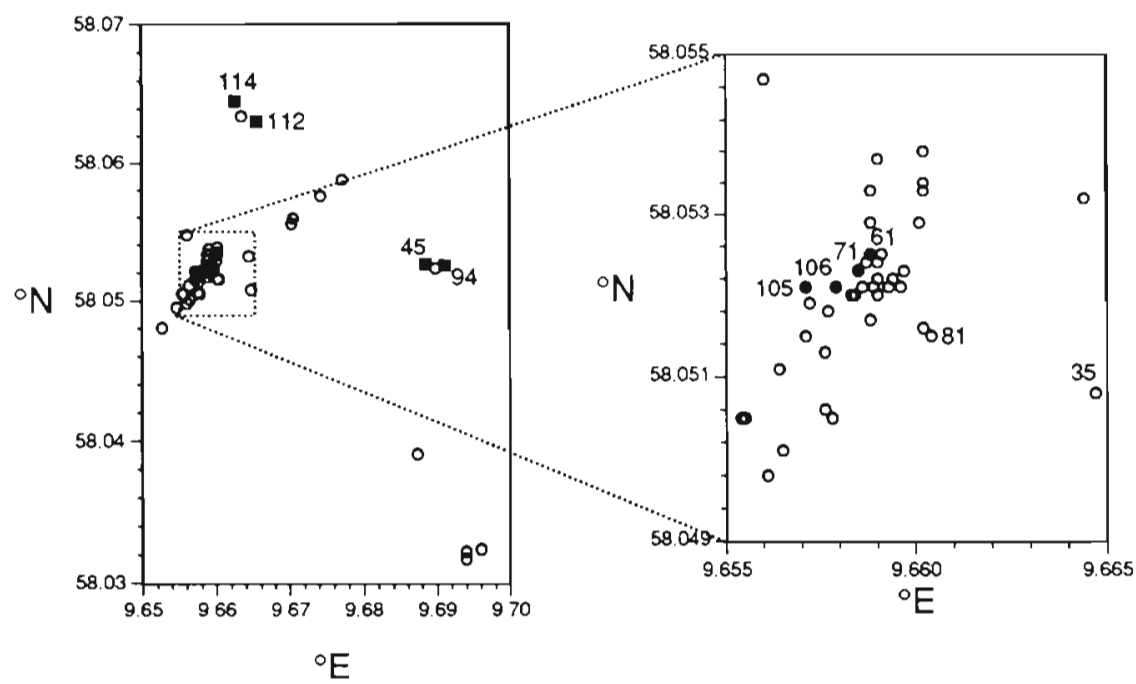

oxidation rates appeared to be high with very low concentrations of dissolved sulphide in most cores, $\leq 3 \mu \mathrm{g} \cdot$ at. $\mathrm{S}^{-1}$, and high elemental sulphur concentrations, up to $7 \times$ $10^{3} \mu \mathrm{g}$-at. S dm${ }^{-3}$ sediment. Sulphate reduction rates increased with sediment depth until approximately $10 \mathrm{~cm}$ depth, reaching a maximum rate in most cores of 46 to $53 \mu \mathrm{g}$ at. sulphate $\mathrm{S}$ reduced $\mathrm{dm}^{-3} \mathrm{~d}^{-1}$, and then remained at a rate of 25 to $50 \mu \mathrm{g}$-at. sulphate $\mathrm{S}$ reduced $\mathrm{dm}^{-3} \mathrm{~d}^{-1}$ until at least $50 \mathrm{~cm}$ depth. These rates increased below $1 \mathrm{~m}$ sediment depth, in the 1 Kasten core studied for sulphate reduction rates these were 64 to $1054 \mathrm{\mu g}$-at. sulphate $\mathrm{S}$ reduced $\mathrm{dm}^{-3} \mathrm{~d}^{-1}$ in the region of low sulphate concentration and methane saturation (Fig. 9b).

In most cores, e.g. Fig. 7 , the $\mathrm{pH}$ of the interstitial water ranged between 7.20 and 7.65 in the upper $2 \mathrm{~cm}$ of sediment to between 7.49 and 8.05 at $50 \mathrm{~cm}$ depth. Interstitial ammonia concentrations varied from between 26 and $500 \mu \mathrm{M}$ in the upper $2 \mathrm{~cm}$ to between 300 and $1400 \mu \mathrm{M}$ at $50 \mathrm{~cm}$ depth. The organic carbon content was variable but normally in the range 1.8 to $2.8 \%$ of dry weight in the upper $50 \mathrm{~cm}$ of sediment.

The major differences from the above results were in cores where methane bubbles were being vented from the surface. One of these cores, from Stn 61 at $333 \mathrm{~m}$ water depth, was venting methane bubbles from approximately 8 outlets on one-half of the box core. Escaping gas had a strong hydrogen sulphide smell. The bubbles brought to the surface black, sulphide-rich mud which flowed over the $1 \mathrm{~mm}$ thick light-brown oxidised sediment surface. None of the bubbles had formed a depression in the sediment surface, as was described by Flügel \& Callsen-Cencic
(1992). A fine brown mat of tubes of the pogonophore Siboglinum poseidoni was exposed at the surface on the seeping half of the box, but none were visible on the non-seeping half. Methane concentrations were in the range $0.7 \times 10^{3}$ to $3.4 \times 10^{3} \mu \mathrm{mol}$ $\mathrm{dm}^{-3}$ in the upper $10 \mathrm{~cm}$ of sediment from the seeping part of the core but were $<10 \mu \mathrm{mol} \mathrm{dm}{ }^{-3}$ in the corresponding horizon in the non-seeping part of the core (Fig. 10a). A transect away from a gas outlet showed that the methane concentration in $5 \mathrm{ml}$ sediment syringe subcores, taken from the sediment surface, decreased from $2.16 \times 10^{3} \mu \mathrm{mol} \mathrm{dm} \mathrm{dm}^{-3}$ to $42 \mathrm{\mu mol} \mathrm{dm}^{-3}$ within $5 \mathrm{~cm}$ (Fig. 11). Methane oxidation rates, measured by the radiotracer method, simi-

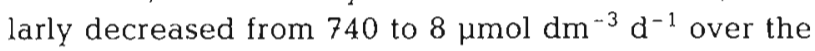
same distance (Fig. 11). 
methane oxidised $\left(\mu \mathrm{mol} \mathrm{dm}{ }^{-3} \mathrm{~d}^{-1}\right) \quad$ sulphate reduced ( $\mu \mathrm{g}$-at. $\mathrm{S} \mathrm{dm} \mathrm{d}^{-3} \mathrm{~d}^{-1}$ )
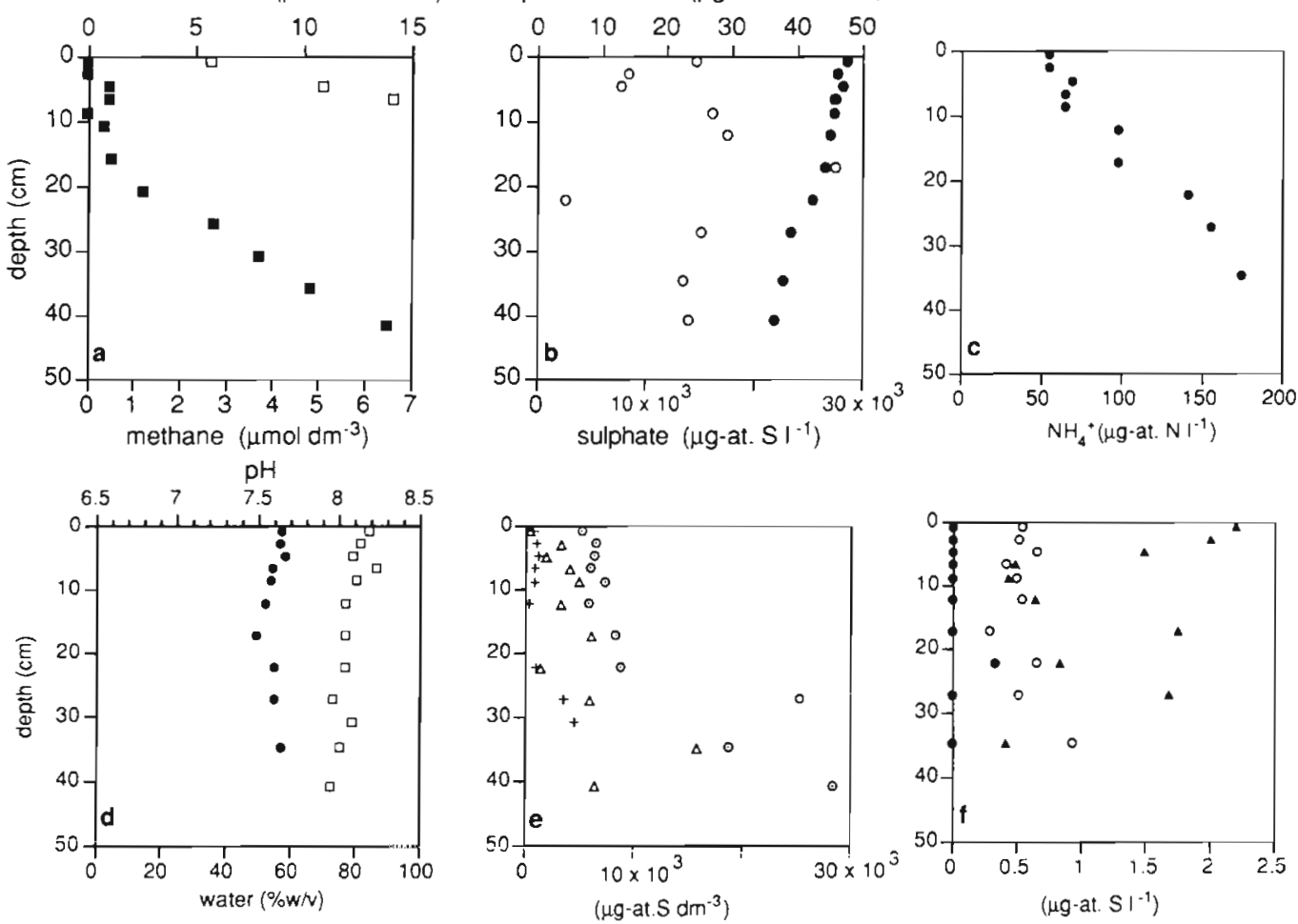

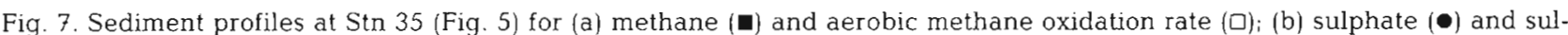
phate reduction rate (O); (c) $\mathrm{NH}_{4}{ }^{+} ;$(d) $\mathrm{pH}(\bullet)$ and water content (ㄷ); (e) $\mathrm{S}^{\circ}(+)$, acid-labile sulphide $(\Delta)$ and chromous reducible sulphide $(0)$; (f) sulphite $(\bullet)$, thiosulphate $(0)$ and sulphide $(\Delta)$ in pore water
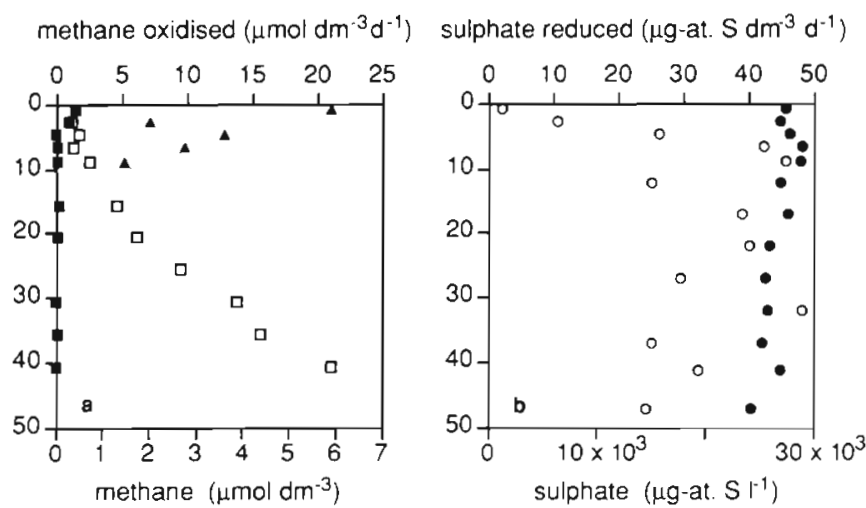

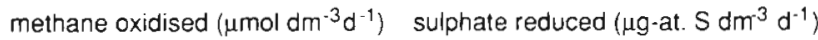
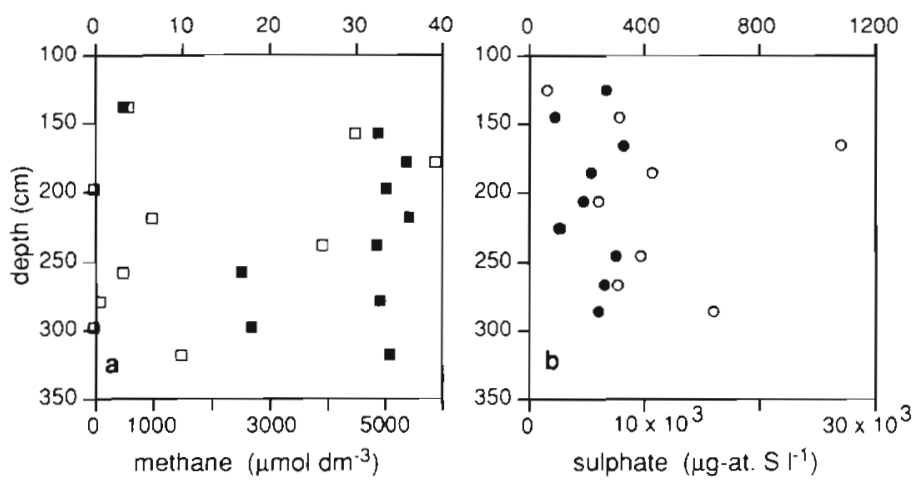

Fig. 8. Profiles at Stn 81 for (a) methane (ㅁ), aerobic methane oxidation rate $(\mathbf{\Lambda})$ and the methane oxidation rate using the radiotracer method ( $\mathbf{\square})$, (b) sulphate ( and sulphate reduction rate $(0)$
Fig. 9. Sediment profiles in a Kasten core taken at Stn 45 for (a) methane ( $\square$ ) and methane oxidation rate using the radiotracer method ( $\square$ ), (b) sulphate ( $\bullet$ ) and sulphate reduction rate $(0)$ 

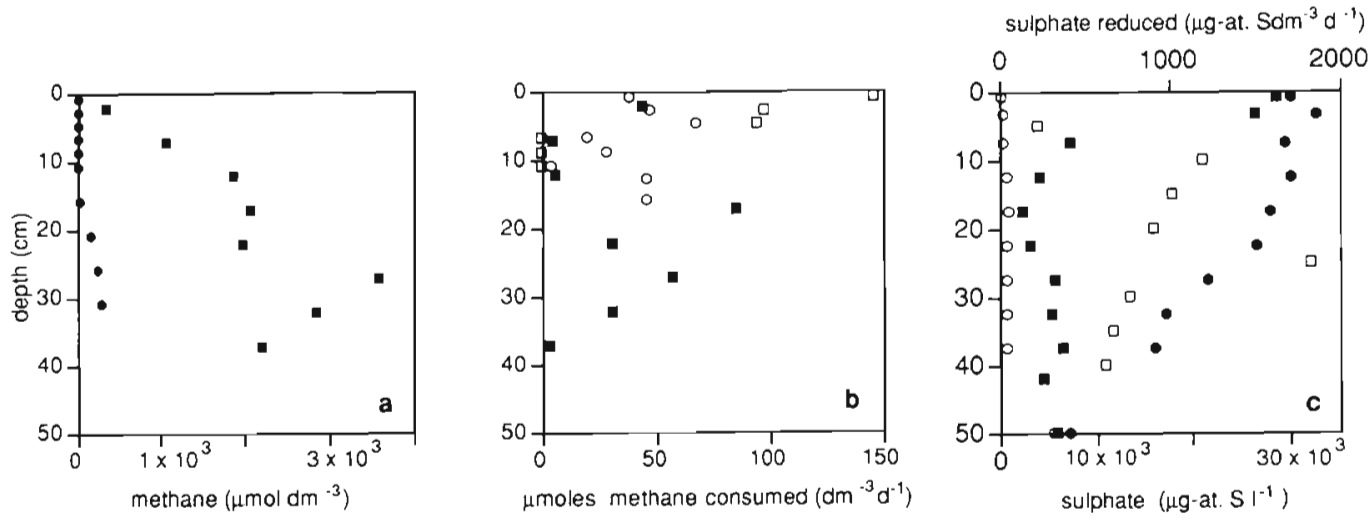

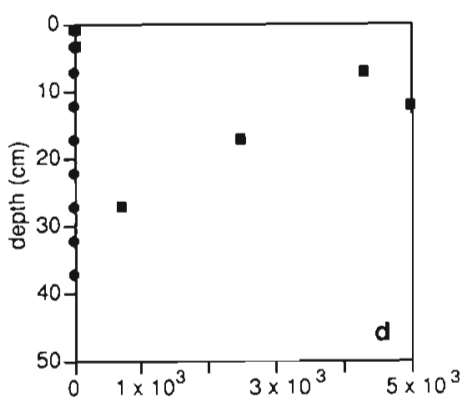

$\mu \mathrm{g}$-at. $\mathrm{S} \mathrm{dm}^{-3}$

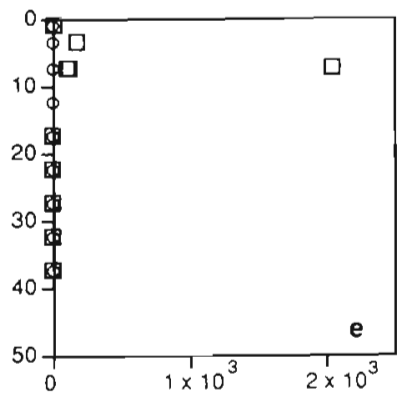

$\mu \mathrm{g}$-at. $\mathrm{S} \mathrm{dm}^{-3}$

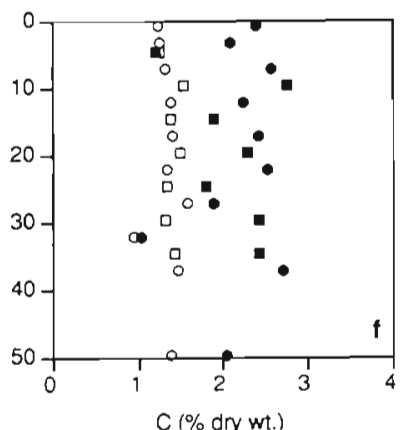

Fig. 10. Sediment profiles in 2 subcores taken $30 \mathrm{~cm}$ apart from the seep box core at Stn 61 . Profiles from the seeping part of the core are shown by squares and profiles from the non-seeping part are shown by circles: (a) methane ( $\bullet$, $\mathbf{\square})$; (b) aerobic methane oxidation rate $(0, \square)$ and methane oxidation using the radiotracer method ( $\boldsymbol{\square})$; (c) sulphate $(\bullet$, $\boldsymbol{\square})$ and sulphate reduction rate $(\mathrm{O}, \square)$; (d) dissolved sulphide $(\bullet, \mathbf{\bullet})$; (e) thiosulphate $(\mathrm{O}, \square)$; (f) $\operatorname{organic}(\bullet, \mathbf{\bullet})$ and inorganic carbon $(\mathrm{O}, \square)$

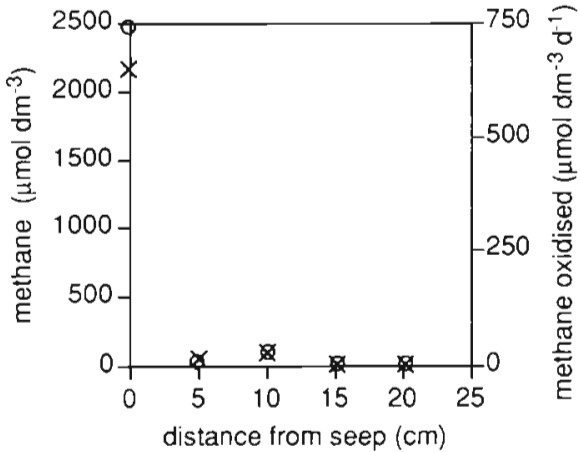

Fig. 11. Sediment transect, from the box core at Stn 61, away from a gas outlet showing methane $(0)$ and methane oxidation rate by the radiotracer method $(x)$ in the upper $5 \mathrm{~cm}$ of sediment

Total non-volatile organic carbon contents were similar for both seep and non-seep sections (Fig. 10f) as were total bacterial counts (Fig. 12). Aerobic methane oxidation rates in sediment suspensions from the seep

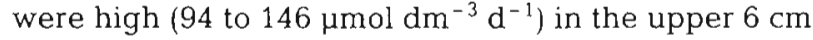
of sediment in the seep area, whereas no activity was found below (Fig. 10b). In the non-seeping part of the core aerobic methane oxidation was lower (4 to

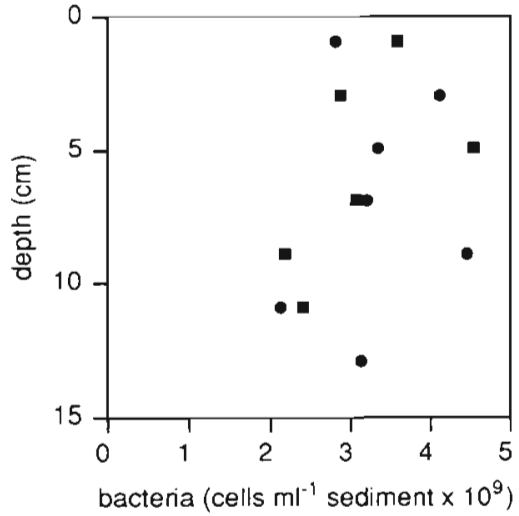

Fig. 12. Sediment profile of bacterial numbers in the seep ( and non-seep (-) parts of the box core from Stn 61

$67 \mu \mathrm{mol} \mathrm{dm}^{-3} \mathrm{~d}^{-1}$ ), but was present to at least $16 \mathrm{~cm}$ sediment depth. Measurements of the methane oxidation rate by the tracer injection method showed a surface maximum close to the seep (Fig. 11) and a subsurface maximum at approximately $15 \mathrm{~cm}$ depth reaching $85 \mu \mathrm{mol} \mathrm{dm}{ }^{-3} \mathrm{~d}^{-1}$ (Fig. 10b). Turnover times, calculated on the integrated values of methane concentration and oxidation rates over the depth sampled, 
Table 1. Species composition of seep and non-seep areas at Stn 61

\begin{tabular}{|c|c|c|c|c|}
\hline \multirow[t]{2}{*}{ Species } & \multicolumn{2}{|c|}{ Seep part of core } & \multicolumn{2}{|c|}{ Non-seep part of core } \\
\hline & no. $m^{-2}$ & $g \mathrm{~m}^{-2}$ & no. $m^{-2}$ & $\mathrm{~g} \mathrm{~m}^{-2}$ \\
\hline Paramphinone jeffreysii & 2767 & & 926 & \\
\hline Other polychaetes & 299 & & 574 & \\
\hline Total polychaete biomass & & 9.2 & & 29.2 \\
\hline Siboglinum poseidoni & 17600 & 76.6 & 50 & 0.2 \\
\hline Abra nitida & 567 & & 303 & \\
\hline Thyasira sarsi & 133 & & 0 & \\
\hline Thyasira equalis & 300 & & 750 & \\
\hline Thyasira eumyaria & 0 & & 83 & \\
\hline Nucula sp. & 33 & & 0 & \\
\hline Total bivalve biomass & & 36.5 & & 9.3 \\
\hline Amphiura sp. & 33 & 2.8 & 0 & \\
\hline Total biomass & & 125.1 & & 38.7 \\
\hline
\end{tabular}

ranged between $42 \mathrm{~d}$ in a non-seep core ( $\operatorname{Stn} 81$ ) to $6 \mathrm{~d}$ in a seep core (Stn 105). Sediment from Stn 61 had a turnover time for methane of $63 \mathrm{~d}$.

The differences in dissolved sulphate profiles from subcores taken $30 \mathrm{~cm}$ apart from the seeping and nongas seeping parts of the core were dramatic (Fig. 10c). Sulphate remained above $27 \times 10^{3} \mu \mathrm{g}$-at. S $\mathrm{l}^{-1}$ in the upper $20 \mathrm{~cm}$ of the non-seep part and then decreased, almost linearly, to $7 \times 10^{3} \mu \mathrm{g}$-at. $\mathrm{S}^{-1}$ at $50 \mathrm{~cm}$ sediment depth. In the seep part of the core sulphate rapidly

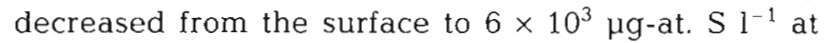
$10 \mathrm{~cm}$ sediment depth and then remained at approximately this concentration for the rest of the core. Sulphate reduction rates, below $10 \mathrm{~cm}$ sediment depth, were in the range $0.5 \times 10^{3}$ to $2 \times 10^{3} \mu \mathrm{g}$-at. $\mathrm{l}^{-1}$ sulphate $S$ reduced $\mathrm{dm}^{-3} \mathrm{~d}^{-1}$; at this rate, in the absence of reoxidation of the sulphide or a replacement of the interstitial water, the sulphate would become exhausted within 3 to $6 \mathrm{~d}$. The sulphate reduction rates for the seep part of the core at Stn 61 were underestimated due to the fact that up to $70 \%$ of the added $\mathrm{K}_{2}{ }^{35} \mathrm{SO}_{4}$ was reduced within the $12 \mathrm{~h}$ incubation period, thus sulphate depletion became significant during the incubation period. The integrated rate for the seep part of the core was $147.8 \times 10^{3} \mu \mathrm{g}$-at. sulphate $\mathrm{S}$ reduced $\mathrm{m}^{-2}$ $\mathrm{d}^{-1}$ for the upper $40 \mathrm{~cm}$ of sediment, compared to $7.1 \times$ $10^{3} \mu \mathrm{g}$-at. sulphate $\mathrm{S}$ for the non-seep part of the core.

Dissolved sulphide concentrations in the methanesaturated part of the core were in the range 0.5 to $500 \mu \mathrm{g}$-at. S $\mathrm{S}^{-1}$, compared to no detectable sulphide in the other half of the box core (Fig. 10d). Thiosulphate concentrations ranged up to $2.05 \times 10^{3} \mu \mathrm{g}$-at. S $\mathrm{I}^{-1}$ in the seep half, compared to between 0.0 and $1.0 \mu \mathrm{g}$-at. $\mathrm{S} \mathrm{I}^{-1}$ in the non-seep part of the box core (Fig. 10e).

The density of Siboglinum poseidoni was 17600 ind. $\mathrm{m}^{-2}$ in the half of the core from which gas was venting, compared to $50 \mathrm{~m}^{-2}$ in the other half of the core. These pogonophores made up $63 \%$ of the wet weight of animals in the seeping part of the core where the total biomass (122 $\mathrm{g} \mathrm{m}^{-2}$ ) was 3-fold higher than that in the non-seeping part of the core (biomass $38.7 \mathrm{~g} \mathrm{~m}^{-2}$ ) (Table 1). The bivalve Thyasira sarsi, at a density of 133 ind. $\mathrm{m}^{-2}$, was responsible for most of the remaining biomass in the seeping half of the core but was absent from the non-seeping section. In contrast the other major thyasirid species present, the smaller $T$. equalis, was more common in the non-seep half, $750 \mathrm{~m}^{-2}$, than in the seep half, $300 \mathrm{~m}^{-2}$. The infauna in the non-seep part of the core was dominated by polychaetes, which at almost $1500 \mathrm{~m}^{-2}$ made up $75 \%$ of the biomass, with almost all the residue being due to the bivalves $T$. equalis and Abra nitida.

The box core collected from Stn 71 was similar to this, except that the zone of outgassing sediment with pogonophores extended only $8 \mathrm{~cm}$ into the $50 \mathrm{~cm}$ box (Fig. 13). In the core from Stn 105 the gas escaped only from the extreme corner, around the edges of a hagfish Myxine glutinosa burrow. A subcore taken alongside the visible gas seep showed the presence of gas bubbles within the sediment at $25 \mathrm{~cm}$ below the surface. In the final seep core, Stn 106, the region of methane- and sulphide-rich sediment again only occurred in one corner and reached from the base of the $68 \mathrm{~cm}$ deep core to within $20 \mathrm{~cm}$ of the sediment surface. More detailed analysis of the fauna collected in the samples will be published elsewhere.

\section{DISCUSSION}

The Skagerrak is a sedimentary basin in which postglacial deposits reach thicknesses up to $90 \mathrm{~m}$ (van Weering 1975). Within the study area the rate of sedi- 
mentation has been calculated to be in the range 1 to $3 \mathrm{~mm} \mathrm{yr}^{-1}$ (van Weering et al. 1987). The resulting rapid carbon burial results in high levels of methane in the sediments. This was first recognised by van Weering et al. (1973) and van Weering (1975) who noted areas of acoustic blanking, 'shadow zones', due to gas bubbles in the sediment. The most recent map of shallow gas occurrence in the Skagerrak is that of Hovland (1991). A zone of acoustic turbidity is seen in the sediments along the southern part of the Skagerrak in water depths from 200 to $300 \mathrm{~m}$ and shallower. The area in water shallower than $90 \mathrm{~m}$ off the northern coast of Denmark had not been surveyed. The present study found that the zone of acoustic turbidity continues inshore to water depths of less than $50 \mathrm{~m}$ off Hirtshals. Within the greater part of this area methane bubbles are present to within $3 \mathrm{~m}$ of the sediment surface, as confirmed by core samples. The shallow gas zone is probably continuous with the one running in a NW-SE direction through the northern part of Vendsyssel (Jessen 1936).

Within the shallow gas area the 'seeps', where methane bubbles escape into the water column, are concentrated in the steeper part of the slope. In this region mounds and slumps occur, exposing the methane-saturated sediment horizons which are otherwise $0.5 \mathrm{~m}$ or more below the surface. Despite the presence of this shallow methane-saturated sediment there is little evidence of large-scale seepage into the water column. The methane concentration profiles indicate that most of the gas is consumed within the sediment (Figs. 7a \& 8a). Within the zone of sediment slumps or hummocks, between 280 and $360 \mathrm{~m}$ depth, acoustically turbid plumes, probably due to gas bubbles, rising from the seabed, have been observed on $18 \mathrm{kHz}$ echosounder records ( $\mathrm{H}$. Flügel \& P. CallsenCencic pers. comm.). Flügel \& Callsen-Cencic (1992) recently collected a box core from this area which contained numerous Siboglinum poseidoni and which vented methane bubbles when brought to the surface. We collected 3 similar venting cores, 2 containing pogonophores, among the 44 taken in this region, i.e. $7 \%$ of the total. The seep cores lay in an approximately NE-SW line parallel to the depth contours in this part of the Skagerrak. None of the $0.25 \mathrm{~m}^{2}$ box cores was seeping methane from its entire area, suggesting that the areas of methane seepage are very small. On the basis of the area of seeping sediment collected in the cores taken we estimate that a maximum of $2.3 \%$ of the region of sediment slumps is seeping gas.

The seeping part of the cores was characterised not only by high methane concentrations in the upper
$10 \mathrm{~cm}$ of sediment but also by high dissolved sulphide and by high sulphate reduction rates. This accounted for the co-distribution of both Siboglinum poseidoni, a gutless pogonophore which derives its nutrition from symbiotic methane-oxidising bacteria (Schmaljohann et al. 1990), and Thyasira sarsi, a bivalve which may obtain the majority of its carbon from symbiotic sulphur-oxidising bacteria in its gills (Dando \& Southward 1986, Dando \& Spiro 1993). T. equalis, the most common thyasirid bivalve in this part of the Skagerrak, was less numerous at the gas seeps. Although $T$. equalis does contain symbiotic sulphur-oxidising bacteria in its gills this species has fewer bacteria than $T$. sarsi (Southward 1986) and appears to be less dependent on the bacterial carbon for its nutrition (Dando \& Spiro 1993).

The 2 methods used for measuring methane oxidation rates are not directly comparable. The suspension method, using identical oxygen and methane concentrations in samples from different sediment layers, allows a comparison of potential rates, corresponding to the distribution of aerobic methane oxidising bacteria. The tracer injection method gives rates close to the actual rates of methane oxidation in the sediment where rates depend on the number of methane-oxidising bacteria and the concentrations of methane and of suitable electron acceptors. It should be noted that these incubations were carried out at in situ temperatures but not at in situ pressures and therefore outgassing of methane in the seep sediments would have occurred. In general the suspension method showed higher rates in surface sediments, corresponding to the expected distribution of aerobic methanotrophs which would be depth limited by oxygen penetration. This in turn would be controlled by macrofaunal burrowing activity. In addition, close to sites of escaping gas bubbles, overlying water is drawn down into the sediment to replace the interstitial water 'pumped' out by the ris- 
ing gas bubbles (Dando et al. 1994, O'Hara et al. 1994). The water draw-down close to gas seeps would allow oxygen to penetrate the sediment deeper than would otherwise be the case. This explains the presence of aerobic methane oxidation in deeper sediment horizons $(\geq 16 \mathrm{~cm}$ ) alongside the gas seep in the core from Stn 61 (Fig. 10b) and also accounts for the sharp reduction in methane concentrations in the sediment alongside the seeps since the rate of diffusion is lower than the water inflow to the gas channels (Dando et al. 1994, O'Hara et al. 1994).

The tracer injection method revealed a second (anaerobic) methane oxidation maximum in deeper horizons. This had previously been reported from the Skagerrak (Iversen \& Jørgensen 1985). The maximum rate occurred at $15 \mathrm{~cm}$, identical to that reported for sediment in Saanich Inlet, Canada (Devol et al. 1984).

The very high sulphate reduction rates, $0.5 \times 10^{3}$ to $1.0 \times 10^{3} \mu \mathrm{g}$-at. sulphate $\mathrm{S}$ reduced $\mathrm{dm}^{-3}$ sediment $\mathrm{d}^{-1}$. clearly associated with the gas seepage, were unexpected. They have not been observed at shallower methaine seep sites in the North Sea and Kattegat (Dando et al. 1991, 1994, Jensen et al. 1992). The high rates in the Skagerrak were found both in the surface sediments of seeps, where methane was outgassing and the concentration of methane was $\geq 2 \times 10^{3} \mu \mathrm{mol}$ $\mathrm{dm}^{-3}$ sediment, and also in methane-saturated sediment in deeper sediment. However the rates are an order of magnitude higher than those observed for methane oxidation by the radiotracer method. It is possible that organic material fixed by the dense pogonophore/bacterial associations helps to fuel the sulphate reduction. The high sulphate reduction rates are believed to be sustained despite low sulphate concentrations due to the gas-flow induced interstitial water circulation within the sediment (Dando et al. 1994) which replenishes the sulphate

The pogonophore Siboglinum poseidoni has a length of up to $19 \mathrm{~cm}$ (Flügel \& Callsen-Cencic 1992). This suggests that its distribution will be limited to regions where substantial methane concentrations are found within the upper $20 \mathrm{~cm}$ of sediment. Since there is no mechanism for active uptake of methane, high concentrations would be needed for methanotrophy by bacteria contained within internal tissues. In the 2 cores in which $S$. poseidoni was found maximum methane concentrations in the upper $20 \mathrm{~cm}$ of the sediment were 280 to $3300 \mu \mathrm{mol}$ $\mathrm{dm}^{-3}$. Earlier reports of concentrations of as low as 1 to $44 \mu \mathrm{mol} \mathrm{kg} \mathrm{kg}^{-1}$ sediment (Schmaljohann \& Flügel 1987. Schmaljohann et al. 1990) may have referred to sediment near to the seeps but in which pogonophores were not found. Over most of the survey area the zone of methane saturation was below $60 \mathrm{~cm}$ with $<1 \mu \mathrm{mol}$ methane $\mathrm{dm}^{-3}$ sediment in the upper $10 \mathrm{~cm}$. This sharp gradient, which is maintained by anaerobic methane oxidation, would prevent juvenile $S$. poseidoni from reaching the extensive underlying biogenic methane deposits. In the fine-grained Skagerrak sediments methane only reaches the upper layers in places where downslope slumping on the steeper part of the slope exposes the gas-saturated sediment or where bioturbation, such as that caused by the burrowing of the hagfish at Stn 105, provides a channel for the underlying gas to escape. This will also release hydrogen sulphide produced in the zone of anaerobic methane oxidation. Methanotrophic activity, both free living and symbiotic, should also provide an input of readily metabolisable organic matter into the sediment and hence increase the sulphate reduction rate. Hydrogen sulphide concentrations in the interstitial water of sediment samples collected away from the seeps were $\leq 3 \mu \mathrm{M}$. The high sulphide concentrations at the seeps will enhance the growth of the bivalve mollusc Thyasira sarsi which is largely dependent on endosymbiotic sulphur-oxidising bacteria for its nutrition.

Acknowledgements. We thank the master and crew of RRS 'Challenger', Colin Brett, David Smith and Nigel Fannin (British Geological Survey, Edinburgh) for geophysical support and interpretation, Margaret Dando and Astrid Durrant for cartography, Adrian Fern (Research Vessel Services, Barry) for computer support at sea, Preben Jensen (University of Copenhagen) and Grant Lawson (University of Southampton) for assistance in faunal sampling and A. J. Southward and E. C. Southward for critical reading of the manuscript. This study was supported by NERC, Statoil, the Institute of Petroleum and by the CEC (MAST programme contract no. 0044).

\section{LITERATURE CITED}

Cavanaugh, C. M., Levering, P. R., Maki, J. S., Mitchell, R., Lidstrom, M. E. (1987). Symbiosis of methylotrophic bacteria and deep-sea mussels. Nature 325: 346-348

Cavanaugh, C. M., Wirsen, C. O., Jannasch, H. W. (1992). Evidence for methylotrophic symbionts in a hydrothermal vent mussel (Bivalvia: Mytilidae) from the mid-Atlantic Ridge. Appl. environ. Microbiol. 56: 3799-3803

Childress, J. J., Fisher, C. R., Brooks, J. M., Kennicutt, M. C., Bidigare, R., Anderson, A. E. (1986). A methanotrophic marine molluscan (Bivalvia, Mytilidae) symbiosis: mussels fueled by gas. Science 233: 1306-1308

Dando, P. R., Austen, M. C., Burke, R. J., Kendall, M. A., Kennicutt, M. C., Judd, A. G., Moore, D. C., Schmaljohann, R., Southward, A. J. (1991). Ecology of a North Sea pockmark with an active methane seep. Mar. Ecol. Prog. Ser. 70: $49-63$

Dando, P. R., O'Hara, S. C. M., Niven, S. J., Schmaljohann, R., Schuster, U., Taylor, L. J. (1994). The effects of methane seepage at an intertidal/ shallow subtidal site on the shore of the Kattegat, Hedestrand, Vendyssel, Denmark. Bull. geol. Soc. Denmark (in press)

Dando, P. R., Southward, A. J. (1986). Chemoautotrophy in bivalve molluscs of the genus Thyasira. J. mar. biol. Ass. U.K. 66: 915-929 
Dando, P. R., Spiro, B. (1993). Varying nutritional dependence of the thyasirid bivalves Thyasira sarsi and T. equalis on chemoautotrophic symbiotic bacteria, demonstrated by isotope ratios of tissue carbon and shell carbonate. Mar. Ecol. Prog. Ser. 92: 151-158

Devol, A. H., Anderson, J. J., Kuivila, K., Murray, J. W. (1984) A model for coupled sulphate reduction and methane oxidation in the sediments of Saanich Inlet. Geochim. Cosmochim. Acta 48: 993-1004

Flügel, H. J., Callsen-Cencic, P. (1992). New observations on the biology of Siboglinum poseidoni Flügel \& Langhof (Pogonophora) from the Skagerrak. Sarsia 77: 287-290

Flügel, H. J., Langhof, I. (1983). A new hermaphroditic pogonophore from the Skagerrak. Sarsia 67: 211-212

Hovland, M. (1991). Large pockmarks, gas-charged sediments and possible clay diapirs in the Skagerrak. Mar. Petroleum Geol. 8: 311-316

Iversen, N., Jørgensen, B. B. (1985). Anaerobic methane oxidation rates at the sulphate-methane transition in marine sediments from Kattegat and Skagerrak (Denmark). Limnol. Oceanogr. 30: 944-955

Jensen, P., Aagaard, I., Burke, R. A., Dando, P. R., Jørgensen, N. O., Kuijpers, A., Laier, T., O'Hara, S. C. M., Schmaljohann, R. (1992). 'Bubbling reefs' in the Kattegat: submarine landscapes of carbonate-cemented rocks support a diverse ecosystem at methane seeps. Mar. Ecol. Prog. Ser. 83: $103-112$

Jessen, A. (1936). Vendsyssels Geologi. Dan. geol. Unders. V(2)

Jorgensen, B. B. (1978). A comparison of methods for the quantification of bacterial sulphate reduction in coastal marine sediments. 1. Measurements with radiotracer techniques. Geomicrobiology J. 1. 11-27

Newton, G. L., Dorian, R., Fahey, R. C. (1981). Analysis of biological thiols: derivatization with monobromobimane and

This article was presented by A. J. Southward, Plymouth, UK separation by reverse-phase high performance liquid chromatography. Analyt. Biochem. 114:383-387

O'Hara, S. C. M., Dando, P. R., Schuster, U., Bennis, A., Boyle, J. D., Chin, F. T W., Hatherell, T. V. J., Niven, S. J., Taylor, L. J. (1994). Gas seep induced interstitial water circulation: observations and environmental implications. Cont. Shelf Res. (in press)

Schmaljohann, R., Faber, E., Whiticar, M. J., Dando, P. R (1990). Co-existence of methane- and sulphur-based endosymbioses between bacteria and invertebrates at a site in the Skagerrak. Mar. Ecol. Prog. Ser. 61: 119-124

Schmaljohann, R., Flügel, H. J. (1987). Methane-oxidising bacteria in Pogonophora. Sarsia 72: 91-98

Southward, A. J., Southward, E. C., Dando, P. R., Rau, G. H., Felbeck, H., Flügel, H. (1981). Bacterial symbionts and low $13 \mathrm{C} / 12 \mathrm{C}$ ratios in tissues of Pogonophora indicate unusual nutrition and metabolism. Nature 293: 616-620

Southward, E. C. (1986). Gill symbionts in thyasirids and other bivalve molluscs. J. mar. biol. Ass. U.K. 66: 889-914

van Weering, T. C. E. (1975). Late Quaternary history of the Skagerrak; an interpretation of acoustical profiles. Geol. Mijnbouw 54: 130-145

van Weering, T. C. E., Berger, G. W., Kalf, J. (1987). Recent. sediment accumulation in the Skagerrak, northeastern North Sea. Neth. J. Sea Res. 21. 177-189

van Weering, T C. E., Jansen, J. H. F., Eismaa, D. (1973) Acoustic reflection profiling of the Norwegian Channel between Oslo and Bergen. Neth. J. Sea Res. 6: 241-263

Zhabina, N. N., Volkov, I. 1. (1978). A method of determination of various sulphur compounds in sea sediments and rocks. In: Krumbein, W. E. (ed.) Environmental biogeochemistry and geomicrobiology, Vol. 3, Methods, metals and assessment. Ann Arbor Science Publishers, Ann Arbor, p. $735-746$

Manuscript first received: November 15, 1993

Revised version accepted: February 8, 1994 